\title{
The Role of the Nasal Cavity in the Pathogenesis of Prion Diseases
}

\author{
Anthony E. Kincaid
}

Citation: Kincaid, A.E. The Role of the Nasal Cavity in the Pathogenesis of Prion Diseases. Viruses 2021, 13, 2287. https://doi.org/10.3390/ v13112287

Academic Editor: Christina Sigurdson

Received: 25 October 2021 Accepted: 11 November 2021 Published: 16 November 2021

Publisher's Note: MDPI stays neutral with regard to jurisdictional claims in published maps and institutional affiliations.

Copyright: (C) 2021 by the author. Licensee MDPI, Basel, Switzerland. This article is an open access article distributed under the terms and conditions of the Creative Commons Attribution (CC BY) license (https:// creativecommons.org/licenses/by/ $4.0 /)$.
Departments of Pharmacy Sciences and Medical Microbiology and Immunology, Creighton University, 2500 California Plaza, Omaha, NE 68178, USA; akincaid@creighton.edu

\begin{abstract}
Prion diseases, or transmissible spongiform encephalopathies (TSEs), are a class of fatal neurodegenerative diseases caused by the entry and spread of infectious prion proteins $\left(\mathrm{PrPSc}^{\mathrm{Sc}}\right)$ in the central nervous system (CNS). These diseases are endemic to certain mammalian animal species that use their sense of smell for a variety of purposes and therefore expose their nasal cavity (NC) to $\mathrm{PrP}^{\mathrm{Sc}}$ in the environment. Prion diseases that affect humans are either inherited due to a mutation of the gene that encodes the prion protein, acquired by exposure to contaminated tissues or medical devices, or develop without a known cause (referred to as sporadic). The purpose of this review is to identify components of the NC that are involved in prion transport and to summarize the evidence that the NC serves as a route of entry (centripetal spread) and/or a source of shedding (centrifugal spread) of $\mathrm{PrP}^{\mathrm{Sc}}$, and thus plays a role in the pathogenesis of the TSEs.
\end{abstract}

Keywords: $\mathrm{PrP}^{\mathrm{Sc}}$; $\mathrm{TSE}$; prions; nasal cavity; prion pathogenesis; olfactory system; prionemia; centripetal; centrifugal

\section{Introduction}

Animals that naturally acquire TSEs, including deer, reindeer, elk, moose, and sheep, have a prominent snout and a well-developed sense of smell. Like many species, they actively use their nose to explore their environment for spatial orientation purposes, social communication, the detection of predators, foraging for food, and the selection of potential mates, and they rely upon their memory of previous olfactory experiences to respond appropriately [1]. Prions can persist in the environment for years and have been detected in several bodily excretions including saliva, feces, urine, and blood and in decaying carcasses, placentas, soil, and plants [2-17]. Thus, it is reasonable to expect that animals expose their nasal cavities (NCs) to $\mathrm{PrP}^{\mathrm{Sc}}$ via direct contact with infected animals or following the inhalation of prions shed in the environment and that the NC may serve as an entry point for animal prion diseases. Moreover, given the demonstration of $\mathrm{PrP}^{\mathrm{Sc}}$ in a variety of animal bodily excretions, it is possible that prions are shed in nasal secretions from affected animals.

Humans also have a well-developed sense of olfaction but are not as behaviorally dependent upon their sense of smell to interact with the surrounding world, and to date, there have been no reports of neuroinvasion via inhalation into the NC of humans $[1,18,19]$. However, there is evidence for prions binding to dust collected from scrapie-affected farms and speculation that the olfactory bulb might serve as an entry site for prion neuroinvasion based on the involvement of olfactory structures in animal and human prion diseases [20-25]. The purpose of this article is to summarize the evidence for the centripetal and centrifugal spread of prions via the NCs of animals, including humans, and to summarize the role of the NC in prion pathogenesis.

\section{Functional Organization of the Nasal Cavity and Prion Pathogenesis}

The mammalian NC is an irregularly shaped airspace within the skull and is the initial segment of the respiratory tract. The mucosae that line the NC are specialized for 
conditioning inhaled air by heating, moistening, and cleaning it and facilitating the sense of olfaction. The walls, floor, roof, and medial septum consist of bone and hyaline cartilage, and the lateral walls have irregular projections of bone, known as conchae or turbinates (Figure 1). The shape, size, and number of these thin bony plates vary between mammals, but in each case, they function to increase the NC surface area and turbulence of the inhaled air, both of which facilitate contact between the inhaled material and the nasal mucosa. The bony and cartilaginous surfaces are lined superficially by epithelial cells that sit on a loose connective tissue layer, the lamina propria, that contains numerous mucosal glands, blood and lymphatic vessels, and nerves (Figure 1). The abundance of mucus glands and blood vessels in the lamina propria is important in moistening and warming inhaled air. There are several types of epithelia that line the surface of the NC, each with morphological features that mediate specific functions, and while different species have different proportions of epithelial types, overall, there is a similar organization. Anteriorly, the vestibule of the $\mathrm{NC}$ is lined by a stratified squamous epithelium that is specialized for resisting abrasive forces. Posterior to the vestibule, the inferior portion of the NC is lined predominantly by respiratory (non-sensory) epithelium, which consists of pseudostratified ciliated columnar epithelium interspersed with mucosal goblet cells (Figure 1). This type of epithelium functions to trap particulate airborne matter in mucus and move it towards the oropharynx via the coordinated movement of cilia. The olfactory (sensory) epithelium is located predominantly in the superior portion of the nasal cavity and contains the olfactory sensory neurons (OSNs) that mediate olfaction (Figure 1). The dendrite of OSNs extends towards the surface of the epithelium and expands to form a knob, which contains a variable number of cilia that extend into the mucus layer of the NC. The cilia contain receptors that bind odorant molecules and transduce odors into electrical signals [26]. Unmyelinated axons of the OSNs project from the base of the cells and collect to form fascicles of the olfactory nerve $(\mathrm{ON})$, cranial nerve I, which projects through openings in the skull, the cribriform plate, to synapse in the olfactory bulb $(\mathrm{OB})$ in the brain (Figure 2). These neurons provide the most direct synaptic connection between a surface of the body, the nasal mucosa, and the central nervous system (CNS) and are vulnerable to inhaled pathogens, providing a potential direct pathway into the brain [27]. An interesting feature of most mammalian OSNs is their continued turnover (the average lifespan is 30-90 days under normal circumstances), with ongoing neurogenesis and continual shedding into the periphery, properties not shared with other neurons reviewed in $[28,29]$. Terrestrial vertebrates have an accessory olfactory structure in the NC, the vomeronasal organs (VNOs). These are paired, blind-ended tubes located in the ventral anterior part of the septum of the NC and contain sensory neurons termed vomeronasal sensory neurons (VSNs) that project their axons into the accessory olfactory bulb. The VNO mediates several aspects of reproductive behavior by detecting and relaying chemosensory information from the environment into the CNS [30].

In support of the potential for the NC to serve as a direct route of entry for inhaled prions to the brain is the observation that olfactory, trigeminal and autonomic nerves that innervate structures in the NC transport some viruses directly to the brain [31-38]. Additionally, the normal isoform of the prion protein $\left(\mathrm{PrP}^{\mathrm{C}}\right)$, which is required for the transmission of prion diseases, is expressed by OSNs of the olfactory epithelium, providing further support for the potential for the direct neuroinvasion of $\operatorname{PrP}^{\mathrm{Sc}}$ following inhalation [39-41]. 


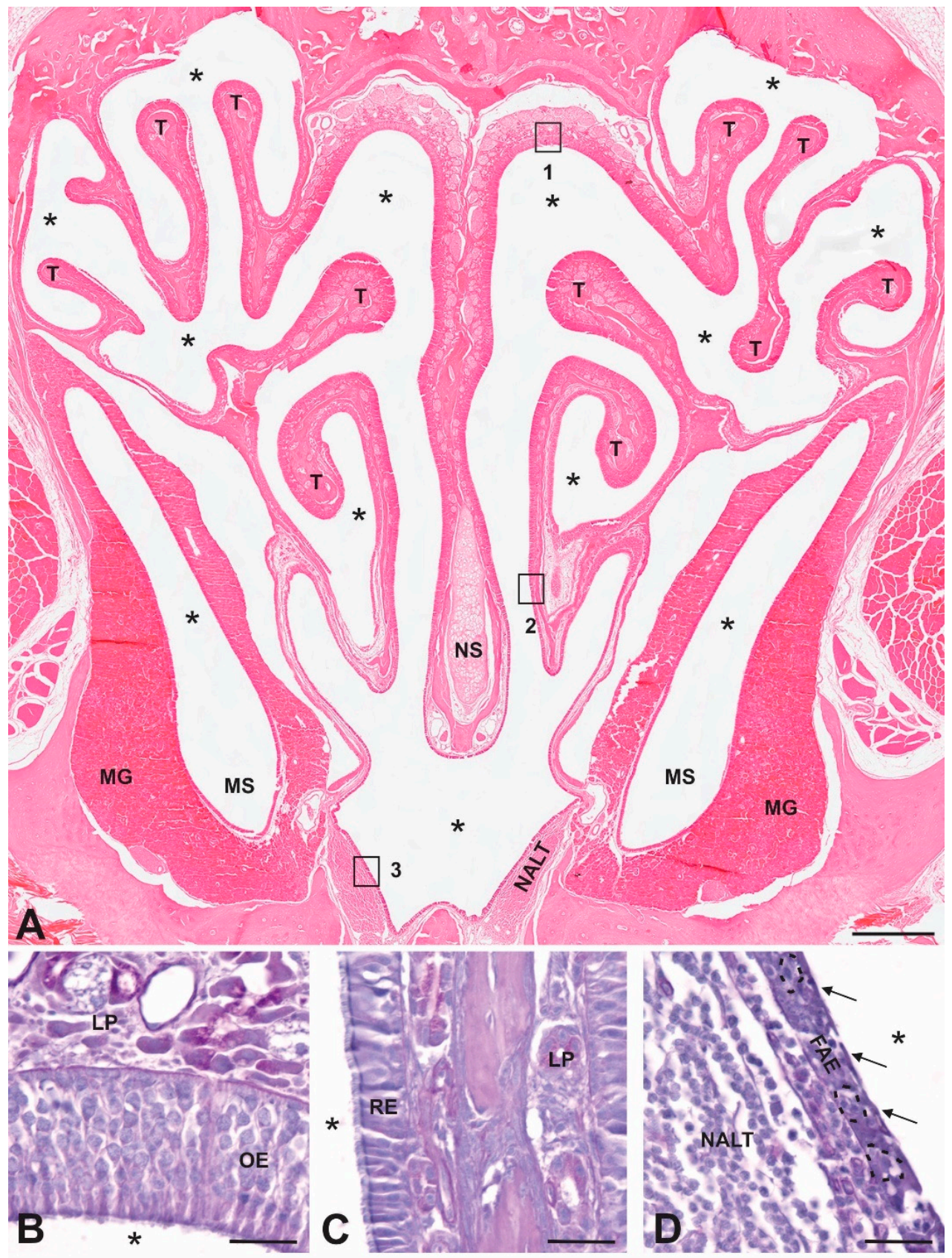

Figure 1. Anatomy of mammalian nasal cavity. (A) H\&E-stained coronal section of a decalcified hamster nasal cavity showing the bony and cartilaginous nasal septum in midline (NS) and the turbinate bones $(\mathrm{T})$ that increase contact between inhaled material and the epithelia that line the cavity. Note the presence of extensive mucus glands (MGs) in the lamina propria surrounding the maxillary sinus (MS) and the unencapsulated nasal associated lymphoid tissue (NALT) in the floor of the NC. Asterisks mark airspaces. Boxes 1-3 are enlarged in panels B-D, respectively. (B) Olfactory epithelium (OE) lines the upper part of the NC and contains olfactory sensory neurons with dendrites that extend into the mucus layer of the NC airspace and axons that collect into nerve fascicles that form the olfactory nerve and project directly into the olfactory bulb of the brain. (C) Respiratory epithelium (RE) contains a single layer of pseudostratified ciliated columnar epithelial cells that overlay a loose connective tissue layer, the lamina propria (LP), that contains mucus glands and blood vessels. (D) Follicle-associated epithelium (FAE) contains microfold cells (M cells; indicated by arrows) that transport antigens in the NC to underlying lymphatic cells in intraepithelial pockets (dotted lines) and the nasal associated lymphoid tissue (NALT). Scale bars: A $=400 \mu \mathrm{m} ; \mathrm{B}, \mathrm{C}$, and $\mathrm{D}=20 \mu \mathrm{m}$. 


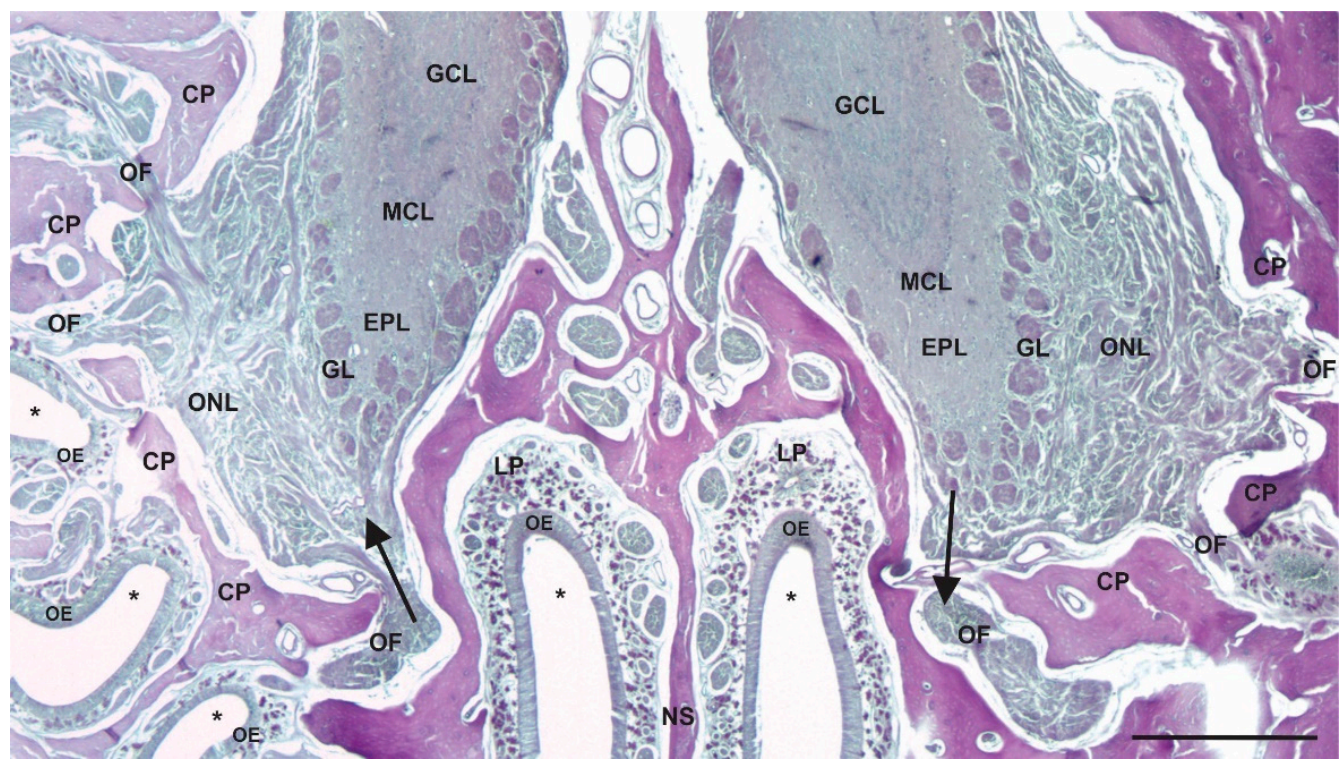

Figure 2. Route for centripetal and centrifugal transport between the olfactory epithelium and olfactory bulbs. A decalcified coronal section of the bony cribriform plate (CP) of the skull, the bony nasal septum (NS), and the superior part of the NC stained with periodic acid-Schiff reagent (asterisks indicate airspace of the NC). The olfactory nerve fascicles (OFs) pass through holes of the $\mathrm{CP}$ connecting the olfactory sensory neurons of the olfactory epithelium (OE) to the glomeruli (GL) of the olfactory bulbs in the CNS. The axons of the olfactory sensory neurons collect into nerve fascicles in the lamina propria (LP) of the superior NC. Note the relatively short and direct route these axons take from the epithelium to the brain. The arrow on the left indicates the direction of centripetal spread, while the arrow on the right indicates the direction of centrifugal spread. $\mathrm{GCL}$ = granule-cell layer; $\mathrm{MCL}=$ mitral-cell layer; $\mathrm{EPL}=$ external plexiform layer; $\mathrm{GL}=$ glomerular layer; $\mathrm{ONL}=$ olfactory-nerve-fiber layer. Scale bar $=400 \mu \mathrm{m}$.

Additional potential contributors to prion entry in the NC are specialized lymphoid structures, the nasal associated lymphoid tissue (NALT). The NALT is unencapsulated collections of lymphocytes and follicular dendritic cells organized into follicles, covered by a follicle-associated epithelium (FAE) that contains microfold (M) cells and is in the ventral NC (Figure 1). Animal species that are experimentally and naturally affected by prion diseases, including mice, hamsters, rats, sheep, cattle, and primates, are known to possess NALT [42-50]. There are two features of the NALT that support the potential for prion entry. First, $\mathrm{M}$ cells are known to transport antigens, including bacteria and viruses, from the airspace of the NC to the underlying lymphoid cells of the NALT, and second, the lymphoid cells of the NALT express relatively high levels of $\operatorname{PrP}^{\mathrm{C}}$ [44,51-53]. It should be noted that the M cells found overlying the NALT are morphologically and functionally similar to the M cells of Peyer's patches in the gut reviewed in [54]. The ringed arrangement of the pharyngeal tonsils, palatine tonsils, lingual tonsils, and tubal tonsils surrounding the junction of the naso- and oropharynx is known as Waldeyer's ring; these lymphoid structures are the first to encounter inhaled or ingested pathogens and are thought to be a human equivalent to NALT [55].

\section{Experimental Evidence for the Role of the NC in Prion Entry following NC Exposure}

\subsection{Efficacy and Efficiency of the NC Route of Entry}

There have been multiple demonstrations that $\mathrm{PrP}^{\mathrm{Sc}}$ inhaled into the nasal cavity causes disease (see Table 1). These studies have been carried out in hamsters [56-58], mice [58,59], transgenic mice [60], sheep [61] and deer [62,63] using different strains of prion-infected brain homogenate (bh) $[56-58,61]$ or aerosolized prions $[59,62,63]$. The 
inoculation of the $\mathrm{NC}$ with infected bh or aerosolized prions resulted in disease in all the animals in these studies with one exception. Hamsters inoculated with the DY strain of transmissible mink encephalopathy (TME), which does not replicate in the peripheral lymphoreticular system, did not develop disease [58,64]. It is worth noting that DY-TME is transported to LRS tissues, and inoculum can be detected, but the replication of prions cannot be detected [64]. In a study where a comparison was made between oral and NC routes of inoculation, the two routes were determined to have similar incubation periods, but the NC route was determined to be 10-100 times more efficient [56]. The increase in efficiency was corroborated in a study of the aerosol transmission of chronic wasting disease (CWD) in white-tailed deer [62]. Thus, a lower dose of inoculum inhaled into the NC caused disease when compared to the ingestion of an infected food pellet. The difference in efficiency between the two routes of infection may be due to the relatively harsh environment of the gut, where alimentary fluids have been shown to markedly degrade prions in sheep $[65,66]$. It is possible in both natural and experimental settings that oral and nasal cavities are exposed to prions as animals explore the environment through sniffing and/or licking and take in relatively large amounts of infectious material through repeated exposures of both cavities; therefore, both routes could be involved in the entry of prions into the body of a given animal.

Table 1. Experimental evidence for centripetal spread of prions via the nasal cavity.

\begin{tabular}{|c|c|c|c|c|c|}
\hline Study (Year) & Species & Inoculum & $\begin{array}{l}\text { Did Exposure to } \\
\text { NC Cause } \\
\text { Disease? }\end{array}$ & $\begin{array}{l}\mathrm{PrP}^{\mathrm{Sc}} \text { in OE Prior } \\
\text { to Detection in } \\
\text { OB/Brain }\end{array}$ & $\begin{array}{l}\text { Detection of PrPSc } \\
\text { in LRS Structures }\end{array}$ \\
\hline $\begin{array}{c}\text { Kincaid and Bartz } \\
(2007)\end{array}$ & Hamster & HY-bh & Yes & No & Yes \\
\hline Hamir et al. (2008) & Sheep & Scrapie-bh & Yes & nd & nd \\
\hline Sbriccoli (2009) & Hamster & 263K-bh & Yes & No & Yes \\
\hline Bessen et al. (2009) & Hamster, mice & $\begin{array}{l}\text { HY or DY-bh; } \\
\text { RML-bh }\end{array}$ & $\begin{array}{l}\text { Yes; except for } \\
\text { DY-inoculated and } \\
\text { most LRS-deficient } \\
\text { mice }\end{array}$ & No & $\begin{array}{l}\text { Yes; except for } \\
\text { LRS-deficient and } \\
\text { DY-inoculated } \\
\text { animals }\end{array}$ \\
\hline $\begin{array}{l}\text { Denkers et al. } \\
(2010)\end{array}$ & Cervidized mice & $\begin{array}{l}\text { CWD-bh or } \\
\text { CWD-aerosol }\end{array}$ & Yes & No & No \\
\hline $\begin{array}{l}\text { Haybaeck et al. } \\
\text { (2011) }\end{array}$ & $\begin{array}{c}\text { Wild-type, } \\
\text { transgenic, or } \\
\text { immunodeficient } \\
\text { mice }\end{array}$ & $\begin{array}{l}\text { RML-bh or } \\
\text { RML-aerosol }\end{array}$ & Yes & nd & $\begin{array}{c}\text { Yes; except for } \\
\text { LRS-deficient mice }\end{array}$ \\
\hline $\begin{array}{l}\text { Nichols et al. } \\
\text { (2013) }\end{array}$ & Deer & $\begin{array}{l}\text { CWD-bh mixed } \\
\text { with soil }\end{array}$ & nd & nd & Yes \\
\hline $\begin{array}{c}\text { Denkers et al. } \\
(2013)\end{array}$ & Deer & CWD-aerosol & Yes & nd & Yes \\
\hline
\end{tabular}

nd—not done; bh—brain homogenate.

\subsection{Mechanisms of Transepithelial Transport and Neuroinvasion following NC Exposure}

For prions to enter the body via the NC following inhalation, they must move from the airspace across the nasal mucosa. Candidate entry mechanisms include direct uptake and transport by OSNs or VSNs, transport across or between olfactory or respiratory epithelial cells, and M-cell transport across the FAE. As discussed earlier, there are examples of the direct neuroinvasion of the brain via the $\mathrm{ON}$ by some substances. However, evidence to identify the transport of $\mathrm{PrP}^{\mathrm{Sc}}$ as centripetal spread (entry into the CNS) versus centrifugal spread (transport from the CNS to peripheral structures) via the ON requires the demonstration of $\mathrm{PrPSc}^{\mathrm{Sc}}$ in the $\mathrm{OM}$ and $\mathrm{ON}$ prior to the appearance of infectious prions in the $\mathrm{OB}$ and AOB. The OB and AOB are the synaptic targets of OSN and VSN axons, respectively, and the demonstration of $\mathrm{PrPSc}^{\mathrm{Sc}}$ in either of these two structures prior to detection in the OSNs or VSNs could be due to the centrifugal spread of prions. To differentiate the centripetal spread from the centrifugal spread of prions requires the collection and analysis 
of NCs throughout the course of the incubation period, and not just the analysis of tissue collected after clinical signs have appeared and $\mathrm{PrP}^{\mathrm{Sc}}$ has likely spread throughout the CNS. There are no reports of $\mathrm{PrP}^{\mathrm{Sc}}$ in OSNs or the ON prior to their detection in the OBs in those studies that have collected tissues, including NCs, prior to the onset of clinical signs [56-58]. The apparent lack of centripetal spread of prions via the ON following inhalation into the NCs of experimental animals is supported by reports in natural hosts. In one study, prions were not detected in either OSNs or the OM in 24 cases of naturally occurring scrapie, and in another study, there was a lack of prion detection in the OM and the OBs of white-tailed deer inoculated with prions complexed to montmorillonite clay 175 days post-inoculation [23,63]. The reason for the apparent lack of centripetal spread of $\operatorname{PrP}^{\mathrm{Sc}}$ via the $\mathrm{ON}$ is not known but may be the relatively low or uneven expression of $\mathrm{PrP}^{\mathrm{C}}$ in OSNs [39,40]. In summary, to date, there is no evidence for the centripetal spread of $\mathrm{PrP}^{\mathrm{Sc}}$ into the CNS via uptake and transport in the $\mathrm{ON}$ following inhalation into the NC. However, the centripetal spread of $\mathrm{PrP}^{\mathrm{Sc}}$ via OSNs or the ON cannot be ruled out definitively, as it is possible that the expression or accumulation levels of $\mathrm{PrP}^{\mathrm{Sc}}$ following NC exposure are below the level of detection of immunohistochemistry (IHC).

Other potential routes of neuroinvasion in the NC include transport via the trigeminal nerve and autonomic nerves known to innervate the nasal mucosa. Free nerve endings of the trigeminal nerve are located within the epithelia of the NC and detect somatosensory stimuli such as touch, pain, and temperature [67]. These peripheral fibers from the ethmoid and nasopalatine branches of the trigeminal nerve course between epithelial cells of the nasal mucosa but generally do not reach the airspace of the $\mathrm{NC}$, terminating deep to the tight junctions that connect adjacent epithelial cells [68]. More recently, a population of solitary chemoreceptor cells was identified scattered across the nasal mucosae of rats and mice [69]. These cells express $\alpha$-gustducin, similar to taste cells on the tongue, and respond to bitter substances; they are thought to mediate protective reflexes such as sneezing, coughing, or apnea in response to inhaled toxins $[69,70]$. These chemosensitive cells extend to the surface of the nasal mucosa and are innervated at their base by peripheral branches of the trigeminal nerve, which puts them in a position to be involved in the neuroinvasion of inhaled prions. Other nerves located in the NC that could potentially transmit prions into the brain are parasympathetic and sympathetic fibers that innervate mucus glands and blood vessels, respectively. The transport of prions via these autonomic fibers could be similar in some respects to the route of neuroinvasion from the gut wall following per os exposure as reported by McBride et al. [71]. However, there have been no reports of prions associated with these nerves, or their respective ganglia, following NC exposure. $\mathrm{PrPSc}^{\mathrm{Sc}}$ has been detected in the spinal trigeminal tract and nucleus, and which are brainstem targets of trigeminal sensory neurons, as early as 100 days after inoculation into the NCs of hamsters ( $60 \%$ of the incubation period). This time point, in the middle of the course of the incubation period, makes it difficult to ascertain if the nerve is a source of the centripetal spread of prions, or if these brain areas are involved via connections with other affected brain areas [57]. There have been no studies that have examined trigeminal ganglia for the presence of $\mathrm{PrP}^{\mathrm{Sc}}$ after the inhalation of infected bh into the $\mathrm{NC}$ to determine if they are involved in the centripetal spread of prions.

There is evidence for the transepithelial transport of inhaled $\mathrm{PrP}^{\mathrm{Sc}}$ via $\mathrm{M}$ cells of the FAE that overlie the NALT and for the paracellular transport of $\mathrm{PrP}^{\mathrm{Sc}}$ between cells of the respiratory epithelium, olfactory epithelium, and FAE [72]. These examples of transepithelial transport in the NC are observed in hamsters and mice 15-180 min following inhalation $[72,73]$. PrP ${ }^{\mathrm{Sc}}$ was detected within a small number of $\mathrm{M}$ cells in the FAE overlying the NALT; this type of transepithelial transport was previously noted in an in vitro model of M-cell transport [74]. Further support for the role of $\mathrm{M}$ cells in $\mathrm{PrP}^{\mathrm{Sc}}$ transport comes from studies that showed that M-cell depletion blocked $\mathrm{PrP}^{\mathrm{Sc}}$ deposition in Peyer's patches, neuroinvasion, and disease development following oral exposure [75]. The paracellular transport of inhaled infected and mock-infected bh was observed in nearly all the animals (hamsters and mice) between epithelial cells of the NC and was neither strain-specific 
nor an artefact of gas anesthesia [72,73]. In these same animals, $\operatorname{PrP}^{\mathrm{Sc}}$ was identified in the lumens of lymphatic vessels in the lamina propria within minutes of the inhalation of prions. The rapid transport of $\mathrm{PrP}^{\mathrm{Sc}}$ across the nasal mucosa and entry into lymphatic vessels is consistent with the early detection of $\mathrm{PrPSc}^{\mathrm{Sc}}$ in the blood of hamsters and deer that was reported to begin within 15 min following inhalation [76,77].

\subsection{The Role of LRS Tissues in Prion Pathogenesis following NC Exposure}

$\operatorname{PrP}^{\mathrm{Sc}}$ has been detected in various LRS tissues following the inhalation of prioninfected bh or aerosol into the NC (Table 1). The LRS tissues that have been examined and found to have $\mathrm{PrP}^{\mathrm{Sc}}$ include lymph nodes [56,58,61,63], tonsils [61-63], spleen [56,58,59] Peyer's patch [56,63], rectoanal mucosa-associated lymphoid tissue (RAMALT) [62], and NALT [56-58]. In some of these studies, the tissues were not collected from animals until after the onset of clinical signs of disease, so it was not possible to determine if the deposition of $\mathrm{PrP}^{\mathrm{Sc}}$ preceded, coincided with, or followed neuroinvasion [58,59,61]. In those studies where tissues were collected from animals at various time points prior to the onset of clinical signs, a temporal analysis of $\mathrm{PrP}^{\mathrm{Sc}}$ deposition in the LRS tissues could be performed $[56,57,62,63]$. The NALT was the first LRS tissue that was identified to contain $\mathrm{PrP}^{\mathrm{Sc}}$ in two studies, as early as $20 \%$ of the incubation period in one study [56] and at $50 \%$ of the incubation period in another [57]. $\mathrm{PrPS}^{\mathrm{Sc}}$ was detected in the tonsils at $25 \%$ and in the RAMALT at $50 \%$ of the incubation period following aerosol transmission to white-tailed deer [62]. In a separate study, $\mathrm{PrPS}^{\mathrm{Sc}}$ was detected in the lymph nodes of white-tailed deer at 3 months following the aerosol transmission of prions bound to montmorillonite clay [63]. In each case, $\mathrm{PrP}^{\mathrm{Sc}}$ was detected in LRS tissues prior to detection in the nervous system, similar to what has been reported when $\mathrm{PrPSc}^{\mathrm{Sc}}$ was ingested via the oral route [78].

Regarding the involvement of the NALT in the pathogenesis of $\operatorname{PrP}^{\mathrm{Sc}}$ entry via NC exposure, it is not clear if prions are transported directly to the NALT following inhalation, or if they reach the NALT via the systemic prionemia that follows the inhalation of prions [76,77]. Regardless of how $\mathrm{PrP}^{\mathrm{Sc}}$ reaches the NALT, it proceeds to progressively accumulate over time, until deposits fill the structure [56]. It is also not clear if there is a mechanism for the transport of $\mathrm{PrP}^{\mathrm{Sc}}$ from the NALT into the CNS, but sympathetic post-ganglionic fibers have been identified within the NALT that might be a source of neuroinvasion [79]. The cell bodies of these fibers are located in the superior cervical ganglion [79] and are synaptically contacted by sympathetic preganglionic fibers that originate from sympathetic preganglionic neurons located in the intermediolateral cell column of the rostral thoracic spinal cord. As mentioned earlier, there have been no reports of $\operatorname{Pr} \mathrm{PSc}^{\mathrm{Sc}}$ in the superior cervical ganglion following the inhalation of prions into the NC.

The ability of inhaled prions to cause disease in mice that lack a functional LRS has led to speculation that $\mathrm{PrPSc}^{\mathrm{Sc}}$ can directly infect the brain via the $\mathrm{ON}$, without a replication phase in lymphoid organs [58,59], but as discussed previously, there is no evidence for the centripetal spread of prions via ONs following inhalation into the NC. The route of neuroinvasion from the NC in these immunodeficient mice remains to be determined.

\section{Evidence for the Presence and Shedding of Prions in Nasal Mucosa and Secretions}

\subsection{Experimental Evidence}

As mentioned previously, OSNs are continuously generated and shed and therefore represent a mechanism for shedding $\mathrm{PrPSc}^{\mathrm{Sc}}$ into the environment. $\mathrm{PrPSc}^{\mathrm{Sc}}$ has been detected in the NC of animals who have demonstrated clinical signs of prion disease (Table 2). Prions were detected in OSNs of the OM and VSNs of the VNO in the NCs of hamsters that were inoculated intracerebrally or directly into the OB with HY-TME $[80,81]$. Transport of PrPSc from the CNS to the OSNs and VSNs in the NC are examples of centrifugal spread of prions, but in these experiments the inoculations, made directly into the cerebrum or OBs, did not model natural routes of exposure and may actually have involved transport by axons damaged by the inoculation (in the case of $\mathrm{OB}$ inoculations). To determine if the centrifugal spread of prions to the NC could occur in animals following a peripheral, and potentially 
natural, route of exposure we examined the NCs of hamsters who inhaled HY-TME bh into their NC and later demonstrated clinical signs of disease. Examination of their NCs demonstrated $\mathrm{PrP}^{\mathrm{Sc}}$ in OSNs of the OM, VSNs of the VNO and in cells located in the FAE and NALT, indicating centrifugal spread of $\mathrm{PrP}^{\mathrm{Sc}}$ and the potential for the shedding of infectious prions in nasal secretions, albeit at the end stage of the clinical course (Figure 3). Infectivity in the nasal mucosa collected from cattle terminally ill with bovine spongiform encephalopathy (BSE) was determined using transgenic mouse bioassay, although $\mathrm{PrP}^{\mathrm{Sc}}$ was not detected in the nasal mucosa using immunohistochemistry or protein misfolding cyclic amplification (PMCA) [82]. In two separate field studies CWD prions were detected in nasal brushings that were collected antemortem from farmed white-tailed deer, and farmed and free ranging Rocky Mountain elk, using real-time quaking-induced conversion (RT-QuIC) in a relatively small proportion of sampled animals who tested positive for CWD infection by other analyses [83,84]. In addition to the detection of $\operatorname{PrP}^{\mathrm{Sc}}$ in the $\mathrm{OM}$, infectivity in the $\mathrm{OM}$ and in nasal secretions collected by nasal lavage from infected hamsters were found to be infectious by bioassay, indicating that infected animals can shed $\operatorname{PrP}^{\mathrm{Sc}}$ via their NC that is potentially infectious [81]. However, these results must be interpreted with caution as the inoculations were made directly into the OBs and the retrograde transport to the OSNs in the OE may be the result of an intranerve inoculation. Additionally, it must be emphasized that the presence of $\mathrm{PrP}^{\mathrm{Sc}}$ in the $\mathrm{NC}$ in each of the experimental studies listed above was noted only at the terminal stages of disease, and thus the period of potential shedding prior to death was relatively short.

Table 2. Evidence for centrifugal spread of $\mathrm{PrP}^{\mathrm{Sc}}$ to nasal cavity.

\begin{tabular}{|c|c|c|c|c|}
\hline Study (Year) & Species & $\begin{array}{l}\text { Route of } \\
\text { Exposure }\end{array}$ & $\begin{array}{l}\text { Means of } \\
\text { Detection }\end{array}$ & $\begin{array}{c}\text { Location of } \\
\operatorname{PrP}^{S c}\end{array}$ \\
\hline $\begin{array}{l}\text { DeJoia et al. } \\
(2006)\end{array}$ & Hamster & IC & IHC; IF & OM; VNE \\
\hline $\begin{array}{l}\text { Bessen et al. } \\
\quad(2010)\end{array}$ & Hamster & $\mathrm{IC} ; \mathrm{IOB}$ & $\begin{array}{l}\text { IHC; IF; WB; } \\
\text { RT QuIC }\end{array}$ & OM; VNE \\
\hline $\begin{array}{l}\text { Haley et al. } \\
\text { (2016) }\end{array}$ & Deer & Not known & $\begin{array}{c}\text { RT QuIC } \\
\text { OM brushings }\end{array}$ & $\mathrm{OM}$ \\
\hline Haley (2016) & Elk & Not known & $\begin{array}{c}\text { RT QuIC } \\
\text { OM brushings }\end{array}$ & $\mathrm{OM}$ \\
\hline $\begin{array}{l}\text { Zanusso et al. } \\
\quad(2003)\end{array}$ & $\begin{array}{l}\text { Human } \\
\text { sCJD }\end{array}$ & none & IHC; WB & $\mathrm{OM}$ \\
\hline $\begin{array}{l}\text { Tabaton et al. } \\
\text { (2004) }\end{array}$ & $\begin{array}{l}\text { Human } \\
\text { sCJD }\end{array}$ & none & $\begin{array}{c}\text { IHC; } \\
\text { immunoblot }\end{array}$ & $\mathrm{OM}$ \\
\hline $\begin{array}{l}\text { Orru et al. } \\
\text { (2014) }\end{array}$ & $\begin{array}{c}\text { Human } \\
\text { sCJD; inherited CJD }\end{array}$ & none & $\begin{array}{c}\text { RT QuIC } \\
\text { OM brushings }\end{array}$ & $\mathrm{OM}$ \\
\hline $\begin{array}{l}\text { Redaelli et al. } \\
\qquad(2017)\end{array}$ & $\begin{array}{l}\text { Human } \\
\text { FFI }\end{array}$ & none & RT QuIC; PMCA & $\mathrm{OM}$ \\
\hline
\end{tabular}

$\overline{\mathrm{IC}}=$ intracerebral; $\mathrm{IOB}=$ intra olfactory bulb. 

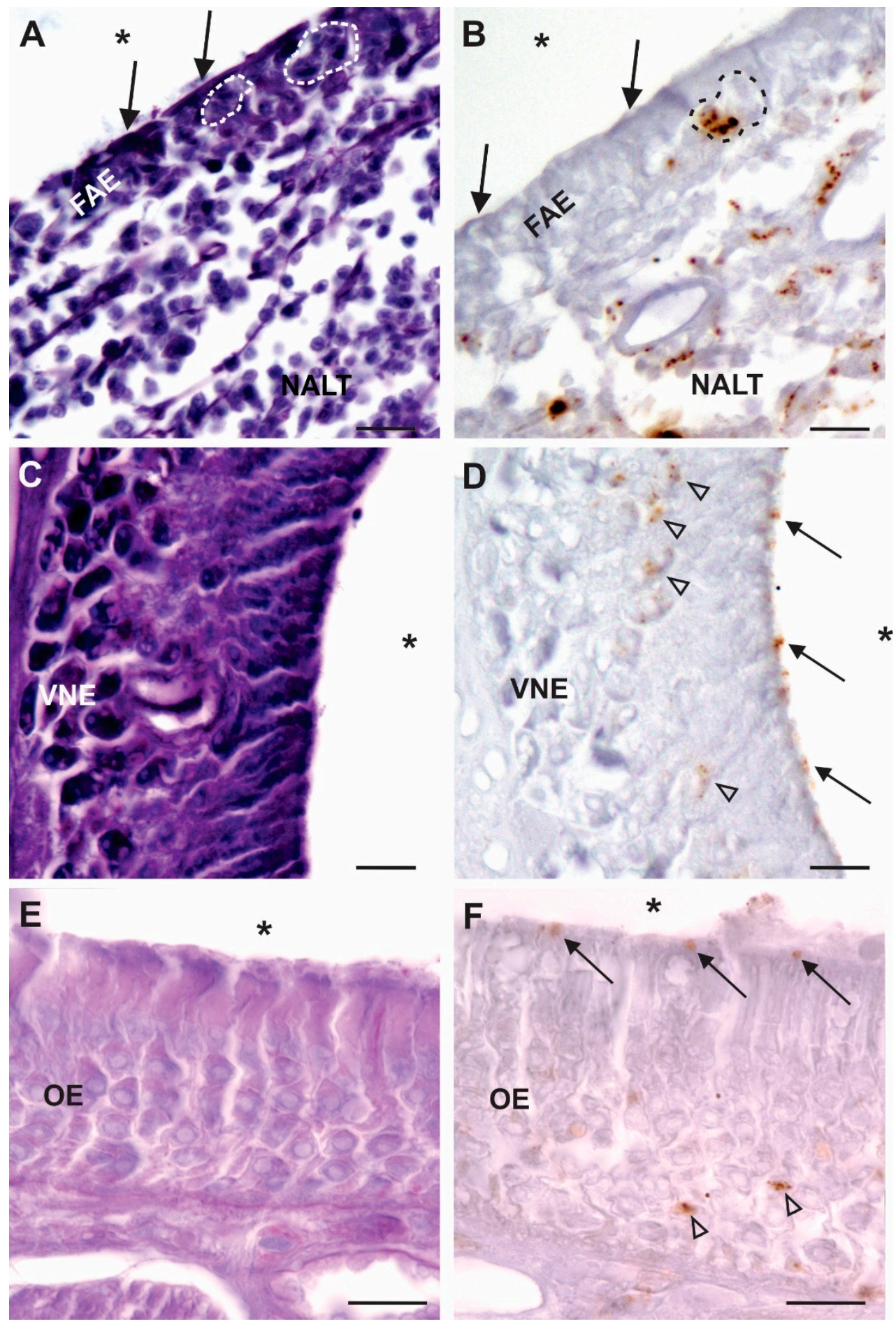

Figure 3. $\mathrm{PrP}^{\mathrm{Sc}}$ in the $\mathrm{NC}$ of clinically ill hamsters following inhalation of prions into the NC (asterisks indicate airspace of the NC). (A,C,E) Periodic acid Schiff-stained sections, and (B,D,F) nearadjacent immunohistochemically processed tissue sections for the presence of $\mathrm{PrP}^{\mathrm{Sc}}$ using the $3 \mathrm{~F} 4$ antibody. (A,B) $\mathrm{PrPSc}^{\mathrm{Sc}}$ in intraepithelial pockets (indicated by dotted lines) of the follicle-associated epithelium (FAE) and the underlying nasal associated lymphoid tissue (NALT). (C,D) $\mathrm{PrPSc}^{\mathrm{Sc}}$ in the vomeronasal epithelium (VNE), in both the cell bodies (indicated by arrowheads) and apical surfaces of the sensory neurons (indicated by solid arrows). (E,F) $\mathrm{PrP}^{\mathrm{Sc}}$ can be seen in the OE, in the OSN cell bodies (indicated by arrowheads), and in dendrites at the apical surfaces of the cells (indicated by solid arrows). Scale bars $=10 \mu \mathrm{m}$. 


\subsection{Evidence from Human Prion Diseases}

Several studies have identified $\mathrm{PrP}^{\mathrm{Sc}}$ in the NCs of humans diagnosed with a prion disease. $\mathrm{PrP}^{\mathrm{Sc}}$ was first identified in the $\mathrm{OM}$ collected postmortem from nine individuals who died with a diagnosis of sporadic Creutzfeldt-Jakob disease (sCJD) [85]. The presence of the prions in the OM of the $\mathrm{NC}$, at the interface between the OSNs and airspace, suggested that $\mathrm{PrP}^{\mathrm{Sc}}$ might be detectable in a non-invasive tissue collection procedure and perhaps provide a convenient means of antemortem diagnosis. The ability for the antemortem detection of a prion disease was subsequently demonstrated by the immunohistochemical detection of $\mathrm{PrP}^{\mathrm{Sc}}$ in an olfactory biopsy collected from an individual with suspected, later confirmed, sporadic CJD [86]. The diagnostic potential for this procedure was confirmed by the application of the RT-QuIC assay on nasal brushings from individuals with both sporadic and inherited CJD [87]. RT-QuIC applied to the OM proved to be both highly specific and sensitive in the diagnosis of Creutzfeldt-Jakob disease, and the sensitivity was greater than that of the RT-QuIC analysis of cerebrospinal fluid collected from these same patients [87]. The sensitivity and specificity of RT-QuIC and PMCA in detecting $\mathrm{PrP}^{\mathrm{Sc}}$ in the $\mathrm{OM}$ of patients with a diagnosed prion disease were confirmed in patients with fatal familial insomnia (FFI), an inherited prion disease [88]. Regarding the potential for the human NC to shed infectious prions, studies using transgenic mice have shown that OM pellets collected from sporadic CJD is infectious, but the amount of infectivity in the OM brushings was more than 10,000-fold less infectious per unit volume than that for infected brain tissue from these same patients. These findings were similar to the results of a transmission study demonstrating that PMCA-generated products from OM obtained from FFI patients inoculated into transgenic mice expressing the bank vole prion protein were infectious [89]. To date, there has been just one study of human nasal secretions (collected from the nasal vestibule), which found prion infectivity in two of 13 samples, indicating that there was lower, and in most cases undetectable, seeding activity in the nasal secretions compared to the OM nasal brushings [90]. Therefore, while the data suggest that the potential for the spread of prion diseases between humans is limited, precautions during surgical procedures involving the nasal cavity are warranted $[89,90]$.

\section{Summary}

\subsection{Centripetal Spread of Prions}

Studies in a variety of animals have demonstrated that multiple prion strains inhaled into the NC cause disease in a relatively efficient manner. Significantly, the inhalation of infected brain homogenate into the NC has not been demonstrated to cause centripetal spread via the $\mathrm{ON}$ into the CNS. Instead, prions have been shown to cross the epithelial lining of the $\mathrm{NC}$ and enter lymphatic vessels in the lamina propria and are detected in the blood within minutes of inhalation. The specific mechanism and route of neuroinvasion following the inhalation of infectious prions has not been determined for any of the animal species examined to date. In contrast to the substantial experimental evidence for the efficient entry of prions via the NC in animals, there is no evidence that humans are infected with prions via exposure through their NC.

\subsection{Centrifugal Spread and Shedding of Prions}

Regarding the role of the NC in the centrifugal spread and shedding of prions, the evidence in experimental animals is limited and must be interpreted with caution. $\mathrm{PrP}^{\mathrm{Sc}}$ was detected in the somata and dendrites of the OSNs of affected animals, and nasal secretions collected from these animals caused disease in recipient animals, but these animals had been inoculated intracerebrally or in the OBs, not by a peripheral route. In animals inoculated by a peripheral route, $\mathrm{PrP}^{\mathrm{Sc}}$ was detected in OSNs but only in animals very late in the incubation period or when they demonstrated clinical signs. Thus, any shedding of prions in nasal secretions that might have taken place would only have occurred for a relatively short period of time. Centrifugally spread prions were noted in the OM of humans affected with prion disease, but the level of infectivity was very low. 
Therefore, while nasal brushings may be a useful diagnostic tool in humans, the evidence for the centrifugal shedding of $\mathrm{PrPSc}^{\mathrm{c}}$ is limited. Taken together, the evidence indicates that the NC is a likely route of entry for prions in animals, but not humans, and that the shedding of $\mathrm{PrP}^{\mathrm{Sc}}$ in nasal secretions as a significant means of transmission is not likely.

Funding: This work was supported by NIH RO1 NS061994 and 1R01 NS107246-01.

Conflicts of Interest: The author declares no conflict of interest.

\section{References}

1. Laska, M. Human and animal olfactory capabilities compared. In Springer Handbook of Odor, 1st ed.; Buettner, A., Ed.; Springer: Cham, Switzerland, 2017; pp. 675-689. [CrossRef]

2. Brown, P.; Gajdusek, D.C. Survival of scrapie virus after 3 year's internment. Lancet 1991, 337, 269-270. [CrossRef]

3. Georgsson, G.; Sigurdarson, S.; Brown, P. Infectious agent of sheep scrapie may persist in the environment for at least 16 years. J. Gen. Virol. 2006, 87, 3737-3740. [CrossRef]

4. Seidel, B.; Thomzig, A.; Buschmann, A.; Groschup, M.H.; Peters, R.; Beekes, M.; Terytze, K. Scrapie agent (Strain 263K) can transmit disease via the oral route after persistence in soil over years. PLoS ONE 2007, 2, e435. [CrossRef]

5. Mathiason, C.K.; Powers, J.G.; Dahmes, S.J.; Osborn, D.A.; Miller, K.V.; Warren, R.J.; Mason, G.L.; Hays, S.A.; Hayes-Klug, J.; Seelig, D.M.; et al. Infectious prions in the saliva and blood of deer with chronic wasting disease. Science 2006, 314, 133-136. [CrossRef] [PubMed]

6. Haley, N.J.; Seelig, D.M.; Zabel, M.D.; Telling, G.C.; Hoover, E.A. Detection of CWD prions in urine and saliva of deer by transgenic mouse bioassay. PLoS ONE 2009, 4, e4848. [CrossRef]

7. Safar, J.G.; Lessard, P.; Tamguney, G.; Freyman, Y.; Deering, C.; Letessier, F.; DeArmond, S.J.; Prusiner, S.B. Transmission and detection of prions in feces. J. Infect. Dis. 2008, 198, 81-89. [CrossRef] [PubMed]

8. Henderson, D.M.; Tennant, J.M.; Haley, N.J.; Denkers, N.D.; Mathiason, C.K.; Hoover, E.A. Detection of chronic wasting disease prion seeding activity in deer and elk feces by real-time quaking-induced conversion. J. Gen. Virol. 2017. [CrossRef] [PubMed]

9. Tennant, J.M.; Li, M.; Henderson, D.M.; Tyer, M.L.; Denkers, N.D.; Haley, N.J.; Mathiason, C.K.; Hoover, E.A. Shedding and stability of CWD prion seeding activity in cervid feces. PLoS ONE 2020, 15, e0227094. [CrossRef]

10. Miller, M.W.; Williams, E.S.; Hobbs, N.T.; Wolfe, L.L. Environmental sources of prion transmission in mule deer. Emerg. Infect. Dis. 2004, 10, 1003-1006. [CrossRef]

11. Miller, M.W.; Williams, E.S. Horizontal prion transmission in mule deer. Nature 2003, 425, 35-36. [CrossRef]

12. Angers, R.C.; Browning, S.R.; Sigurdarson, C.J.; Miller, M.W.; Hoover, E.A.; Telling, G.C. Prions in skeletal muscle of deer with chronic wasting disease. Science 2006, 311, 1117. [CrossRef] [PubMed]

13. Nalls, A.V.; McNulty, E.; Hoover, C.E.; Pulscher, L.A.; Hoover, E.A.; Mathiason, C.M. Infectious prions in the pregnancy microenvironment of chronic wasting disease-infected of Reeves' muntjac deer. J. Virol. 2017, 91, e00501-e005017. [CrossRef] [PubMed]

14. Johnson, C.J.; Phillips, K.E.; Schramm, P.T.; McKenzie, D.; Aiken, J.M.; Pedersen, J.A. Prions adhere to soil minerals and remain infectious. PLoS Pathog. 2006, 2, e32. [CrossRef] [PubMed]

15. Johnson, C.J.; Pedersen, J.A.; Chappell, R.J.; McKenzie, D.; Aiken, J.M. Oral transmissibility of prion disease is enhanced by binding to soil particles. PLoS Pathog. 2007, 3, e93. [CrossRef] [PubMed]

16. Saunders, S.E.; Bartelt-Hunt, S.L.; Bartz, J.C. Prions in the environment. Prion 2008, 2, 162-169. [CrossRef]

17. Pritzkow, S.; Morales, R.; Moda, F.; Khan, U.; Telling, G.C.; Hoover, E.; Soto, C. Grass plants bind, retain, uptake and transport infectious prions. Cell Rep. 2015, 11, 1168-1175. [CrossRef]

18. McGann, J.P. Poor human olfaction is a 19th-century myth. Science 2017, 356, eaam7263. [CrossRef]

19. Stitz, L.; Aguzzi, A. Aerosols, an underestimated vehicle for transmission of prion diseases? Prion 2011, 5, 1-4. [CrossRef]

20. Gough, K.C.; Baker, C.A.; Simmons, H.A.; Hawkins, S.A.; Maddison, B.C. Circulation of prions within dust on a scrapie affected farm. Vet. Res. 2015, 46, 40. [CrossRef]

21. Rey, N.L.; Wesson, D.W.; Brundin, P. The olfactory bulb as the entry site for prion-like propagation in neurodegenerative diseases. Neurobiol. Dis. 2018, 109, 226-248. [CrossRef]

22. Doty, R.L. The olfactory vector hypothesis of neurodegenerative disease: Is it viable? Ann. Neurol. 2008, 63, 7-15. [CrossRef] [PubMed]

23. Corona, C.; Porcario, C.; Martucci, F.; Iulini, B.; Manea, B.; Gallo, M.; Palmitessa, C.; Maurella, C.; Mazza, M.; Pezzolato, M.; et al. Olfactory system involvement in natural scrapie disease. J. Virol. 2009, 83, 3657-3667. [CrossRef]

24. Lee, Y.H.; Simmons, M.M.; Hawkins, S.A.C.; Spencer, Y.I.; Webb, P.; Stack, M.J.; Wells, G.A.H. Detection of pathologic prion protein in the olfactory bulb of natural and experimental bovine spongiform encephalopathy affected cattle in Great Britain. Vet. Pathol. 2009, 46, 59-62. [CrossRef]

25. Reuber, M.; Al-Din, A.S.N.; Baborie, A.; Chakrabarty, A. New variant Creutzfeldt-Jakob disease presenting with loss of taste and smell. J. Neurol. Neurosurg. Psych. 2001, 71, 412-418. [CrossRef]

26. Farbman, A.I. Cell Biology of Olfaction; Cambridge University Press: Cambridge, UK, 1992; pp. $24-69$. 
27. Harkema, J.R.; Carey, S.A.; Wagner, J.G. The nose revisited: A brief review of the comparative structure, function, and toxicologic pathology of the nasal epithelium. Tox. Pathol. 2006, 34, 252-269. [CrossRef] [PubMed]

28. Calof, A.L.; Hagiwara, N.; Holcomb, J.D.; Mumm, J.S.; Shou, J. Neurogenesis and cell death in olfactory epithelium. J. Neurobiol. 1996, 30, 67-81. [CrossRef]

29. Brann, J.H.; Firestein, S.J. A lifetime of neurogenesis in the olfactory system. Front. Neurosci. 2014, 8, 182. [CrossRef] [PubMed]

30. Doving, K.B.; Trotier, D. Structure and function of the vomeronasal organ. J. Exp. Biol. 1998, 201, 2913-2925. [CrossRef]

31. Faber, J.K.; Gebhardt, L.P. Localizations of the virus of poliomyelitis in the central nervous system during the preparalytic period after intranasal instillation. J. Exp. Med. 1933, 57, 933-954. [CrossRef] [PubMed]

32. Lafay, F.; Coulon, P.; Astic, L.; Saucier, D.; Riche, D.; Holley, A.; Flamand, A. Spread of the CVS strain of rabies virus and of the avirulent mutant Av01 along the olfactory pathways of the mouse after intranasal inoculation. Virology 1991, 183, 320-330. [CrossRef]

33. Reiss, C.S.; Plakhov, I.V.; Komatsu, T. Viral replication in olfactory receptor neurons and entry into the olfactory bulb and brain. Ann. N. Y. Acad. Sci. 1998, 855, 751-761. [CrossRef]

34. Mori, I.; Nishiyama, Y.; Yokochi, T.; Kimura, Y. Olfactory transmission of neurotropic viruses. J. Neur. Vir. 2005, 11, 129-137. [CrossRef]

35. Van Riel, D.; Verdijk, R.; Kuiken, T. The olfactory nerve: A shortcut for influenza and other viral diseases into the central nervous system. J. Pathol. 2014, 235, 277-287. [CrossRef] [PubMed]

36. Kritas, S.K.; Nauwynck, H.J.; Pensaert, M.B. Dissemination of wild-type and gC-, gE- and gI-deleted mutants of Aujeszky's disease virus in the maxillary nerve and trigeminal ganglion of pigs after intranasal inoculation. J. Gen. Virol. 1995, 76, $2063-2066$. [CrossRef]

37. Babic, N.; Mettenleiter, T.C.; Ugolini, G.; Flamand, A.; Coulon, P. Propagation of pseudorabies virus in the nervous system of the mouse after intranasal inoculation. Virology 1994, 204, 616-625. [CrossRef] [PubMed]

38. Matsuda, K.; Park, C.H.; Sunden, Y.; Kimura, T.; Ochiai, K.; Kida, H.; Umemura, T. The vagus nerve is one route of transneuronal invasion for intranasally inoculated influenza A virus in mice. Vet. Pathol. 2004, 41, 101-107. [CrossRef] [PubMed]

39. Le Pichon, C.E.; Firestein, S. Expression and localization of the prion protein $\mathrm{PrP}^{\mathrm{C}}$ in the olfactory system of the mouse. J. Comp. Neurol. 2008, 508, 487-499. [CrossRef]

40. Dibattista, M.; Massimino, M.L.; Maurya, D.K.; Menini, A.; Bertoli, A.; Sortago, M.C. The cellular prion protein is expressed by olfactory sensory neurons of adult mice but does not affect the early events of the olfactory transduction pathway. Chem. Senses 2011, 36, 791-797. [CrossRef] [PubMed]

41. Brandner, S.; Raeber, A.; Sailer, A.; Blattler, T.; Fischer, M.; Weissmann, C.; Aguzzi, A. Normal host prion protein (PrPC) is required for scrapie spread within the central nervous system. Proc. Natl. Acad. Sci. USA 1996, 93, 13148-13151. [CrossRef]

42. Kraal, G. Nasal associated lymphoid tissue. In Mucosal Immunity, 3rd ed.; Mestecky, J., Lamm, M.E., Strober, W., Bienenstock, J., McGhee, J.R., Mayer, L., Eds.; Elsevier Academic Press: Cambridge, MA, USA, 2005; Volume 1, pp. 415-422. [CrossRef]

43. Asanuma, H.; Thompson, A.H.; Iwasaki, T.; Sato, Y.; Inaba, Y.; Aizawa, C.; Kurata, T.; Tamura, S. Isolation and characterization of mouse nasal-associated lymphoid tissue. J. Immun. Meth. 1997, 202, 123-131. [CrossRef]

44. Giannasca, P.J.; Boden, J.A.; Monath, T.P. Targeted delivery of antigen to hamster nasal lymphoid tissue with M-cell directed lectins. Infect. Immun. 1997, 65, 4288-4298. [CrossRef]

45. Spit, B.J.; Hendriksen, E.G.J.; Bruijntjes, J.P.; Kuper, C.F. Nasal lymphoid tissue in the rat. Cell Tissue Res. 1989, 255, 193-198. [CrossRef]

46. Stanley, A.C.; Huntley, J.F.; Jeffrey, M.; Buxton, D. Characterization of ovine nasal-associated lymphoid tissue and identification of $\mathrm{M}$ cells in the overlying follicle-associated epithelium. J. Comp. Path. 2001, 125, 262-270. [CrossRef]

47. Sedgmen, B.J.; Lofthouse, S.A.; Meeusen, E.N. The ovine nasal mucosa: An alternative tissue site for mucosal immunization. Methods 2006, 38, 112-116. [CrossRef] [PubMed]

48. Rebelatto, M.C. Nasal Associated Lymphoid Tissue and Intranasal Immunization in Cattle. Ph.D. Thesis, Purdue University, West Lafayette, IN, USA, 2000.

49. Loo, S.K.; Chin, K.N. Lymphoid tissue in the nasal mucosa of primates, with particular reference to intraepithelial lymphocytes. J. Anat. 1974, 117, 249-259.

50. Debertin, A.S.; Tschernig, T.; Tonjes, H.; Kleemann, W.J.; Troger, H.D.; Pabst, R. Nasal-associated lymphoid tissue (NALT): Frequency and localization in young children. Clin. Exp. Immunol. 2003, 134, 503-507. [CrossRef]

51. Park, J.-S.; Francis, K.P.; Yu, J.; Cleary, P.P. Membranous cells in nasal-associated lymphoid tissue: A portal of entry for the respiratory mucosal pathogen group A streptococcus. J. Immunol. 2003, 171, 2532-2537. [CrossRef]

52. Date, Y.; Ebisawa, M.; Fukuda, S.; Shima, H.; Obata, Y.; Takahashi, D.; Kato, T.; Hanazato, M.; Nakato, G.; Williams, I.R.; et al. NALT M cells are important for immune induction for the common mucosal immune system. Int. Immunol. 2017, 29, 471-478. [CrossRef] [PubMed]

53. Clouse, M.D.; Shikiya, R.A.; Bartz, J.C.; Kincaid, A.E. Nasal associated lymphoid tissue of the Syrian golden hamster expresses high levels of PrPC. PLoS ONE 2015, 10, e0117935. [CrossRef]

54. Dillon, A.; Lo, D.D. M cells: Intelligent engineering of mucosal immune surveillance. Front. Immunol. 2019, 10, 1499. [CrossRef] [PubMed] 
55. Koornstra, P.J.; Duijvestijn, A.M.; Vlek, L.F.M.; Marres, E.H.M.A.; Van Breda Vriesman, P.J.C. Immunohistology of nasopharyngeal (Waldeyer's ring equivalent) lymphoid tissue in the rat. Acta Otolaryngol. 1993, 113, 660-667. [CrossRef] [PubMed]

56. Kincaid, A.E.; Bartz, J.C. The nasal cavity is a route for prion infection in hamsters. J. Virol. 2007, 81, 4482-4491. [CrossRef]

57. Sbriccoli, M.; Cardone, F.; Valanzano, A.; Lu, M.; Graziano, S.; De Pascalis, A.; Ingrosso, L.; Zanusso, G.; Monaco, S.; Bentivoglio, M.; et al. Neuroinvasion of the $263 \mathrm{~K}$ scrapie strain after intranasal administration occurs through olfactory-unrelated pathways. Acta Neuropathol. 2009, 117, 175-184. [CrossRef] [PubMed]

58. Bessen, R.A.; Martinka, S.; Kelly, J.; Gonzalez, D. Role of the lymphoreticular system in prion neuroinvasion from the oral and nasal mucosa. J. Virol. 2009, 83, 6435-6445. [CrossRef] [PubMed]

59. Haybaeck, J.; Heikenwalder, M.; Klevenz, B.; Schwarz, P.; Margalith, I.; Bridel, C.; Mertz, K.; Zirdum, E.; Petsch, B.; Fuchs, T.J.; et al. Aerosols transmit prions to immunocompetent and immunodeficient mice. PLoS Pathog. 2011, 7, e1001257. [CrossRef]

60. Denkers, N.D.; Seelig, D.M.; Telling, G.C.; Hoover, E.A. Aerosol and nasal transmission of chronic wasting disease in cervidized mice. J. Gen. Virol. 2010, 91, 1651-1658. [CrossRef]

61. Hamir, A.N.; Kunkle, R.A.; Richt, J.A.; Miller, J.M.; Greenlee, J.J. Experimental transmission of US scrapie agent by nasal, peritoneal, and conjunctival routes to genetically susceptible sheep. Vet. Pathol. 2008, 45, 7-11. [CrossRef]

62. Denkers, N.D.; Hayes-Klug, J.; Anderson, K.R.; Seelig, D.M.; Haley, N.J.; Dahmes, S.J.; Osborn, D.A.; Miller, K.V.; Warren, R.J.; Mathiason, C.K.; et al. Aerosol transmission of chronic wasting disease in white-tailed deer. J. Virol. 2013, 87, 1890-1892. [CrossRef] [PubMed]

63. Nichols, T.A.; Spraker, T.R.; Rigg, T.D.; Meyerett-Reid, C.; Hoover, C.; Michel, B.; Bian, J.; Hoover, E.; Gidlewski, T.; Balachandran, A.; et al. Intranasal inoculation of white-tailed deer (Odocoileus virginianus) with lyophilized chronic wasting disease prion particulate complexed to montmorillonite clay. PLoS ONE 2013, 8, e62455. [CrossRef]

64. Shikiya, R.A.; Langenfeld, K.A.; Eckland, T.E.; Trinh, J.; Holec, S.M.; Mathiason, C.K.; Kincaid, A.E.; Bartz, J.C. PrPSc formation and clearance as determinants of prion tropism. PLoS Pathog. 2017, 13, e1006298. [CrossRef] [PubMed]

65. Jeffrey, M.; Gonzalez, L.; Espenes, A.; Press, C.M.; Martin, S.; Chaplin, M.; Davis, L.; Landsverk, T.; MacAldowie, C.; Eaton, S.; et al. Transportation of prion protein across the intestinal mucosa of scrapie-susceptible and scrapie-resistant sheep. J. Pathol. 2006, 209, 4-14. [CrossRef] [PubMed]

66. Dagleish, M.P.; Hamilton, S.; Gonzalez, L.; Eaton, S.L.; Steele, P.; Finlayson, J.; Siso, S.; Pang, Y.; Sales, J.; Chianini, F.; et al. Digestion and transportation of bovine spongiform encephalopathy-derived prion protein in the sheep intestine. J. Gen. Virol. 2010, 91, 3116-3123. [CrossRef] [PubMed]

67. Bryant, B.; Silver, W.L. Chemesthesis: The common chemical sense. In The Neurobiology of Taste and Smell, 2nd ed.; Finger, T.E., Silver, W.L., Restrepo, D., Eds.; John Wiley and Sons: Hoboken, NJ, USA, 2000; pp. 73-100.

68. Finger, T.E.; Jeor, V.L.S.; Kinnamon, J.C.; Silver, W.L. Ultrastructure of substance-P and CGRP-immunoreactive nerve fibers in the nasal epithelium of rodents. J. Comp. Neurol. 1990, 294, 293-305. [CrossRef]

69. Finger, T.E.; Bottger, B.; Hansen, A.; Anderson, K.T.; Alimohammadi, H.; Silver, W.L. Solitary chemoreceptor cells in the nasal cavity serve as sentinels of respiration. Proc. Natl. Acad. Sci.USA 2003, 100, 8981-8986. [CrossRef]

70. Sbarbati, A.; Osculati, F. The taste cell-related diffuse chemosensory system. Prog. Neurobiol. 2005, 75, 295-307. [CrossRef] [PubMed]

71. McBride, P.A.; Schulz-Schaeffer, W.J.; Donaldson, M.; Bruce, M.; Diringer, H.; Kretzschmar, H.A.; Beekes, M. Early spread of scrapie from the gastrointestinal tract to the central nervous system involves autonomic fibers of the splanchnic and vagus nerves. J. Virol. 2001, 75, 9320-9327. [CrossRef] [PubMed]

72. Kincaid, A.E.; Hudson, K.F.; Richey, M.W.; Bartz, J.C. Rapid transepithelial transport of prions following inhalation. J. Virol. 2012, 86, 12731-12740. [CrossRef] [PubMed]

73. Kincaid, A.E.; Bartz, J.C. Specificity, size, and frequency of spaces that characterize the mechanism of bulk transepithelial transport of prions in the nasal cavities of hamsters and mice. J. Virol. 2016, 90, 8293-8301. [CrossRef]

74. Heppner, F.L.; Christ, A.D.; Klein, M.A.; Prinz, M.; Fried, M.; Kraehenbuhl, J.-P.; Aguzzi, A. Transepithelial prion transport by M cells. Nat. Med. 2001, 7, 976-977. [CrossRef]

75. Donaldson, D.S.; Kobayashi, A.; Ohno, H.; Yagita, H.; Williams, I.R.; Mabbott, N.A. M cell-depletion blocks oral prion disease pathogenesis. Mucosa Immunol. 2011, 5, 216-225. [CrossRef]

76. Elder, A.M.; Henderson, D.M.; Nalls, A.V.; Wilham, J.M.; Caughey, B.W.; Hoover, E.A.; Kincaid, A.E.; Bartz, J.C.; Mathiason, C.K. In vitro detection of prionemia in TSE-infected cervids and hamsters. PLoS ONE 2013, 8, e80203. [CrossRef]

77. Elder, A.M.; Henderson, D.M.; Nalls, A.V.; Hoover, E.A.; Kincaid, A.E.; Bartz, J.C.; Mathiason, C.K. Immediate and ongoing detection of prions in the blood of hamsters and deer following oral, nasal, or blood inoculations. J. Virol. 2015, 89, 7421-7424. [CrossRef] [PubMed]

78. Beekes, M.; McBride, P.A. The spread of prions through the body in naturally acquired transmissible spongiform encephalopathies. FEBS J. 2007, 274, 588-605. [CrossRef]

79. Marafetti, L.E.; Romeo, H.E. Origins of the sympathetic innervation of the nasal-associated lymphoid tissue (NALT): An anatomical substrate for a neuroimmune connection. J. Neuroimmunol. 2014, 276, 119-225. [CrossRef]

80. DeJoia, C.; Moreaux, B.; O'Connell, K.; Bessen, R.A. Prion infection of oral and nasal mucosa. J. Virol. 2006, 80, 4546-4556. [CrossRef] [PubMed] 
81. Bessen, R.A.; Shearin, H.; Martinka, S.; Boharski, R.; Lowe, D.; Wilham, J.M.; Caughey, B.; Wiley, J.A. Prion shedding from olfactory neurons into nasal secretions. PLoS Pathog. 2010, 6, e1000837. [CrossRef] [PubMed]

82. Balkema-Buschmann, A.; Eiden, M.; Hoffmann, C.; Kaatz, M.; Ziegler, U.; Keller, M.; Groschup, M.H. BSE infectivity in the absence of detectable PrPSc accumulation in the tongue and nasal mucosa of terminally disease cattle. J. Gen. Virol. 2011, 92, 467-476. [CrossRef]

83. Haley, N.J.; Siepker, C.; Walter, W.D.; Thomsen, B.V.; Greenlee, J.J.; Lekmkuhl, A.D.; Richt, J.A. Antemortem detection of chronic wasting disease prions in nasal brush collections and rectal biopsy specimens from white-tailed deer by real-time quaking-induced conversion. J. Clin. Microbiol. 2016, 54, 1108-1116. [CrossRef]

84. Haley, N.J.; Siepker, C.; Hoon-Hanks, L.L.; Mitchell, G.; Walter, W.D.; Manca, M.; Monello, R.J.; Powers, J.G.; Wild, M.A.; Hoover, E.A.; et al. Seeded amplification of chronic wasting disease prions in nasal brushings and recto-anal mucosa-associated lymphoid tissue from elk by real-time quaking-induced conversion. J. Clin. Microbiol. 2016, 54, 1117-1126. [CrossRef]

85. Zanusso, G.; Ferrari, S.; Cardone, F.; Zampieri, P.; Gelati, M.; Fiorini, M.; Farinazzo, A.; Gardiman, M.; Cavallaro, T.; Bentivoglio, M.; et al. Detection of pathologic prion protein in the olfactory epithelium in sporadic Creutzfeldt-Jakob disease. N. Eng. J. Med. 2003, 348, 711-719. [CrossRef]

86. Tabaton, M.; Monaco, S.; Cordone, M.P.; Colucci, M.; Giaccone, G.; Tagliavini, F.; Zanusso, G. Prion deposition in olfactory biopsy of sporadic Creutzfeldt-Jakob disease. Ann. Neurol. 2004, 55, 294-296. [CrossRef] [PubMed]

87. Orru, C.D.; Bongianni, M.; Tonoli, G.; Ferrari, S.; Hughson, A.G.; Groveman, B.R.; Fiorini, M.; Pocchiari, M.; Monaco, S.; Caughey, B.; et al. A test for Creutzfeldt-Jakob disease using nasal brushings. N. Eng. J. Med. 2014, 371, 519-529. [CrossRef] [PubMed]

88. Redaelli, V.; Bistaffa, E.; Zanusso, G.; Salzano, G.; Sacchetto, L.; Rossi, M.; DeLuca, C.M.G.; DiBari, M.; Portaleone, S.M.; Agrini, U.; et al. Detection of prion seeding activity in the olfactory mucosa of patients with Fatal Familial Insomnia. Sci. Rep. 2017, 7, 46269. [CrossRef]

89. Bistaffa, E.; Marin-Moreno, A.; Espinosa, J.C.; DeLuca, C.M.G.; Cazzaniga, F.A.; Portaleone, S.M.; Celauro, L.; Legname, G.; Giaccone, G.; Torres, J.M.; et al. PMCA-generated prions from the olfactory mucosa of patients with Fatal Familial Insomnia cause prion disease in mice. eLife 2021, 10, e65311. [CrossRef] [PubMed]

90. Raymond, G.J.; Race, B.; Orru, C.D.; Raymond, L.D.; Bongianni, M.; Fiorini, M.; Groveman, B.R.; Ferrari, S.; Sacchetto, L.; Hughson, A.G.; et al. Transmission of CJD from nasal brushings but not spinal fluid or RT-Quic product. Ann. Clin. Transl. Neurol. 2020, 51057. [CrossRef] [PubMed] 